\title{
一鉄鋼 ニューズー
}

\section{ミナス製鉄所建設計画の進行}

フラシルのミナス敖鉄所建設調查団は，同製鉄所建設 契約の調印を終り，6月9日㷌国したが，その契約の具 体的内容は次の通りとのことである。

一.調四は6月 3 日堀越団長上ブラジル開発審議会代 表ラナリ氏よの間に行われた。クビチエック大統領の㒛 可き経て発效するが，2 力月位で許可される見込.ブラ ジ僋は建設急いでおり，明年1月から着エしたいと いっている.

一・リ゙・ドーセ河流域のアセジッタ製鉄所の隣接地 胥建設用地とする.これはピトリア港からの鉄鉱不輸出 の带りの船舶礼よで鉄道を利用して石炭案供給てきると いうよい立地条件がある。

一. 製鉄所の規模は, 年間銈塊 50 万 $\mathrm{t}$, 鋼材 36 万 $\mathrm{t}$ の 生産总目標として，6力年計画て日産 $700 \mathrm{t}$ 高炉 2 基 はしめ, 焼結設備, コークス設借, 副産物没備, 酸素利 用による転炉設備，分塊設備，120in 厚板製造設備， 72 in の半連続式熱間ストりップ設備，56in 冷間ストリッ

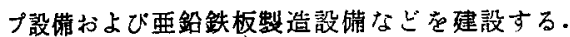

一. 完全運転までは6力年かかるが, 建設後 3 年半後

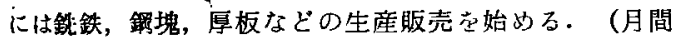
厚板は $13,000 \mathbf{t}$ 觉目標)

一. 資本金の出資比率は日本 4 ブラジル6で日本側の 出算は 16 億クルゼイ口（円換算約 80 億円，1クルゼ イロ 5 円の割) 建設に伴う日本からのブラント輸出は約 38 檍クルゼイ口（円換算約 300 億円，1クルゼイロの 割合8円）自込む.ブラジ側は日本からのクレジッ トて棅㳦類は全部日本に発注したいといっている。

一. 日本側は乙の契約調用にもこついて，ブラジル大 流領の許可があり次第，鉄鎆，機珹会社なじの共同で， シナス製鉄所投資会社を設立することにならう。

\section{科学技術情報センターの発足}

日本科学技街情報センターは，第一期計画として 3 力 年間総額 3 億 3 千万円をうつて理工学部范設立，さらに 第二期計画で医学，農学部和よび地方支所范設置，第三 期計画で全面的に規模 拡大する予定でいる。本年度は 政府出資金 4 千万円，補助金 3 千万円，合計 7 千万円と 同額の民間出資金および寄付金で運営されることになつ て扰り，7月上旬の発足を期し，諸般の隻備が進められ ている。

\section{八憣の新擪板工場完成}

八憣製鉄所では，1昨年秋から八幡地区に新厚板工埸

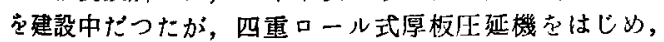
加熱炻，前後面テーブル，エッジング・ロール，丸刃剪 断機などの据付を完了.6月25日から試圧延を行い，7 月から操業を開始する.

同工場は 8 植延べ 16,000 陫におよび，月，月産能力は $35,000 \mathrm{t}$, 差当り月産 $10,000 \mathrm{t}$ 程度てはしめ, 11 月か

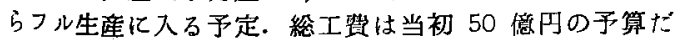
つたが計西変更，工事費高滕などこ78偲円かかつたと いう.
主要設俥の四重ロール式瓜延機は，米园のユナイテッ ト・・エンシニア社製. 従来の二電ロール式に比べ,

(1) 厚板に中ぶくれ密生じな. (2) 長さ $20 \mathrm{~m}$, 巾3・4 $\mathrm{m}$ (従来は $14 \mathrm{~m}, 3 \cdot 2 \mathrm{~m}$ ) の大型厚板范生産できる。 (3) 压姃步留りは 2 割向上し，作業人員は 4 割程度です むなどの特徵をもつているという. 同工場の完成で，現 在の第 2 圧延工場（月産能力 $15,000 \mathrm{t}$ ) は 7 月 18 日限 りで閉鉙.テーブル，剪断㙨などな新厚板工場へ移設す る.

な扰将来は第 2 期工尃上して月産能力 $45,000 \mathrm{t}$ に增 强する計画で，この場合現在の第 1 厚板工場（月産能力 10,000 t) も閉鋿，新厚板工場で集中生産することにな つている.

\section{室澜線材工埸の改造}

富士製銥では，第二次合理化計画の一環として，約 6

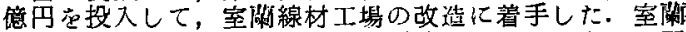
製鉄所の線材工場はてれまで並行仕上ロールによって圧 延してきたが，今回これて全面的に連続式に改造するこ とになつたもので，改造される設備の概要は炊のように なつている。

連続ロールの雨動機范レ*ナルド方式の直流とし，第 1, 第 2 連続口一ル機のさき亿中間口ール機 2 基, 苀上 ロール機6基，巻取機定新設する。これらの機栈は米国 U.E. 社の設計による国内製品茄用いることにし，新設 備に上る㹈品の方法も，とれましの $5.5 \sim 9.5 \mathrm{~mm}$ から 5〜9.5 mm と小径のものが生産できるようになり，ま たコイルの重量も現在の $80 \mathrm{~kg} か ら 270 \mathrm{~kg}$ に增大され， 生産能力方現在の月産 $15,000 \mathrm{t}$ 污 $20,000 \mathrm{t}$ 亿上荘す る予定である。

工事は明年 4 月完成ね目標にしているが，所要スタン ドは，同所鋳銿工場で盽込みを行つている。

\section{住友金属製管設備を改造}

住友金属工業では，和歌山製造所の製管設備を改造， 10月 2 日試圧に入る計画赏進好ているが, 同社の計画に

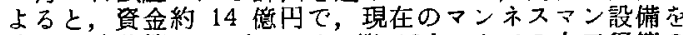
改造. 油茾管 $13 \cdot 3$ in, ガ又管 12 in までの大口径管の 生産莡企図しているものである。この完成は9月の予定 飞，10月には，試圧荧完了し，11月汃ら大径管の本格 稼動官開始する予定.とのため完成後の能力は現在の月 産 8,000 t 加ら $20,000 \mathrm{t}$ に倍半增加される。

\section{耐火煤瓦の生産}

耐火煉瓦の生産は 29 年 度 631，（旦位千 $\mathbf{t}$ ，以下同 E) 30 年度 738,31 年度 875,32 年度 (推定) 975 と 年々に增加し，てのうち鉄銅部門の占める比率は29 年 度 $65 \%, 30$ 年度 $68 \%, 31$ 年度 $68 \% 32$ 年度 $70 \%$ 上 上昇している.

また最近に扣ける生産，出荷，在麻の推移は次の通り である。

$\begin{array}{rccc} & \text { 生産 } & \text { 出荷 } & \text { 在庫（些位于t) } \\ \text { 32年 } 1 \text { 月 } & 71 & 69 & 59 \\ \text { 2月 } & 73 & 74 & 56 \\ \text { 3月 } & 73 & 71 & 58 \\ \text { 4月 } & 73 & 71 & 58 \\ \text { 5月 } & 75 & 73 & 56 \\ \text { 6月 } & 80 & 77 & 54\end{array}$

このため鉄鎆メーカーおよひ耐火煉瓦メ一カーでは,

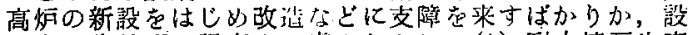

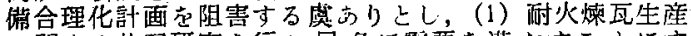

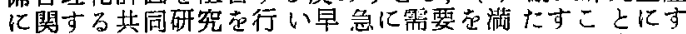
る. (2) 耐火畑瓦の規格を統一することに上つて大量生

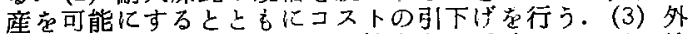

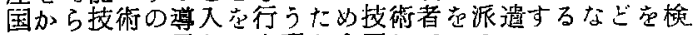
討して扣り，早急な契現定企図したいる。 